\section{Scholarships for the Study of Tuberculosis}

The Italian Fascist National Federation against Tuberculosis has placed at the disposal of the International Union against Tuberculosis six scholarships at the Carlo Forlanini Institute in Rome. These scholarships are of the value of 2,000 lire each, plus board and lodging, and are intended to enable foreign medical practitioners to study at the Carlo Forlanini Institute. They will be awarded by preference to young physicians already familiar with tuberculosis problems who wish to improve their knowledge of this branch of medicine. Candidates should send their names, ages, qualifications and professional experience to the Secretariat, Union internationale contre la Tuberculose, 66 Boulevard St. Michel, Paris, not later than July 1.

\section{Royal Society of Arts: Prizes for Navigation}

Througr the Thomas Gray Memorial Trust, the Royal Society of Arts offered last year a prize of $£ 75$ for an invention, publication, diagram, etc., which was considered to be an advancement in the science or practice of navigation, proposed or invented in the period January 1, 1932-December 31, 1937. Thirty-six entries were submitted. The judges were of the opinion that none of the inventions put forward was deserving of the full prize, but they decided to make the following awards : $£ 25$ to W. Sommerville, of Benton, Northumberland, for his system of instruction and examination in the rule of the road at sea; $£ 25$ to Lieut.-Commander P. V. H. Weems, Annapolis, Maryland, U.S.A., for his second-setting watch. A prize of $£ 25$ for an essay on "The Stability of Ships" has been awarded to H. David, of Ely, Cardiff. The following prizes are offered for 1938 : a prize of $£ 25$ for an invention, publication, diagram, etc., which is considered to be an advancement in the science or practice of navigation, proposed or invented in the period January 1, 1933-December 31, 1938; a prize of $£ 25$ for an essay on a navigational subject. Further information can be obtained from the Secretary, Royal Society of Arts, John Street, Adelphi, London, W.C.2.

\section{Announcements}

Sir Aldo Castellani has been elected an honorary member of the Hanseatic University of Hamburg.

Dr. Friedrich Paschen, professor of experimental physics in the University of Berlin, has been made an honorary member of the Rumanian Academy at Bucharest.

A Portrait medal designed by Dr. Robert Tait McKenzie, Canadian physician and sculptor, has been struck to celebrate the fiftieth anniversary of the foundation of the American Society of Anatomists in memory of its first president, Joseph Leidy, who died in 1891 .

AN Order of Public Health has been created by a decree of the French Government, to be awarded by the Ministry of Health to those who have made outstanding achievements in public health or social service. It will consist of the three ranks of knights, officers and commanders.

ThE eighth International Congress of Military Medicine will be held at Luxemburg on July 1-4. In addition to the usual discussions on military medicine, the following subjects will be dealt with : (1) legislation on aerial protection; (2) scientific study of aerial protection; (3) demonstration of medical aviation.

THe National Institute of Industrial Psychology's vacation course in psychological methods of vocational guidance will be held on August 1-13 at the London School of Economics, where a course will also be held during the same period on the administration of Binet-Simon tests of intelligence. The fee for the former course is five guineas and for the latter course three guineas. Further information can be obtained from the Secretary of the Institute of Industrial Psychology, Aldwych House, W.C.2.

THE summer meeting of the American Association for the Advancement of Science will be held in Ottawa on June 27-July 2. Science and Society Conferences are being organized by the Section on the Social and Economic Sciences, under the general direction of Dr. Harold G. Moulton, and the first conference was held at Indianapolis last December on the subject "Fundamental Resources as Affected by Science". The subject of the Ottawa Conference will be "Science and the Future".

THE programme of the summer school in physics to be held at the University of Reading under the auspices of the Institute of Physics on July 7-9 has recently been issued. The following lectures will be given, and these will be followed by discussion : Prof. J. A. Crowther, "Physics in Biology"; Dr. C. E. Wynn-Williams, "Some Electronic Devices and their Applications"; Dr. O. Klemperer, "The Theory and Practice of Electron Optical Devices"; Dr. E. A. Guggenheim, "Thermodynamics of Low Temperatures"; Dr. W. F. K. Wynne-Jones, "The Significance of Interfacial Potentials"; Dr. C. G. Sumner, "Interfacial Potentials in Systems of Industrial Importance". Membership of the School is open to all interested. Further information can be obtained from the Secretary, Institute of Physics, 1 Lowther Gardens, Exhibition Row, London, S.W.7.

WE are informed that the brochure entitled "The Story of Vitamin $B_{1}$ ", referred to in NATURE of June 4, p. 1006, is issued by Messrs. Merck and Co., Inc., of Rahway, New Jersey.

Erratum.-The great eruption of Mt. Pelé on May 8, 1902, referred to by Dr. C. T. Trechmann in NATURE of March 12, p. 435, occurred at 8 a.m., not 8 p.m. as stated. 